\title{
The Evaluation of Sexual and Vegetative Propagation of Medicinal Plant Christia vespertilionis (Butterfly Wing Plant)
}

\author{
Ramisah Mohd Shah ${ }^{1, *}$, Nur Affida Abd. Rahman ${ }^{1}$, Iffah Hazirah Mohd Nawi ${ }^{1}$, \\ Nor Idzwana Mohd Idris ${ }^{1}$, Rudiyanto ${ }^{1}$, Norhidayah Che $\mathrm{Soh}^{2}$ \\ ${ }^{1}$ Laboratory of Crop Science, Faculty of Fisheries and Food Sciences, Universiti Malaysia Terengganu, Malaysia \\ ${ }^{2}$ Institute of Agricultural and Food Policy Studies, Universiti Putra Malaysia, Serdang, Selangor, Malaysia \\ *Corresponding author. Email: ramisah@umt.edu.my
}

\begin{abstract}
Christia vespertilionis also known as butterfly wing plant is an ornamental and valuable medicinal plant grown in tropical and subtropical regions. Despite the importance, not much attention has been given to study economical propagation methods of $C$. vespertilionis. This work aims to evaluate between sexual (seeds) and vegetative (cuttings and in vitro) propagation techniques in terms of their viability and growth. Pretreatment of seeds showed that wet paper towel was observed induced a higher percentage of germination rate as compared to other treatments. A comparison between two types of cuttings indicated semi hardwood part propagated better than the softwood part. In the present study, in vitro shoot proliferation was obtained by culturing nodal node segments in Murashige and Skoog (MS) medium supplemented with $2.0 \mathrm{mg} / \mathrm{L}$ of 6Benzyl amino purine (BAP). However, no root development was observed when well-developed shoots were transferred on rooting medium supplemented with various concentrations of Indolebutyric acid (IBA). We conclude that $C$. vespertilionis appear to propagate easily using seeds and semi-woody cuttings. Further investigation of in vitro propagation could potentially be used for future conservation and sustainable production of $C$. vespertilionis.
\end{abstract}

Keywords: Christia vespertilionis, sexual and vegetative propagation, in vitro

\section{INTRODUCTION}

In the modern era, medicinal plants are valuable and high demand due to their biochemical properties such as antitumor, antimicrobials, and antioxidants. Christia vespertilionis or butterfly wing plant is an herbaceous perennial plant and can be categorized as an ornamental plant [1]. The plant has very unique trifoliate leaves shaped and contains promising anti-inflammatory and anticancer properties [2]; [3].

Study on the details of $C$. vespertilionis seed germination viability and vegetative propagation involving in vitro culture. Thus, this study was carried out to evaluate various propagation methods includes seed, stem cuttings and in vitro culture of $C$. vespertilionis. Comparison of these propagation techniques may provide useful information for the farmers in order to produce a large scale of $C$. vespertilionis planting material.

\section{METHODS}

Experiments were carried out at the Laboratory of Crop Science and Shade house, Faculty of Fisheries and Food Sciences, Universiti Malaysia Terengganu.
Plant propagation is a process producing new plants and it can be by sexual or vegetative methods. Sexual method involves floral parts of the plant and produced seed. Vegetative or asexual propagation produced new plant from any vegetative parts of the plant such as cuttings, tuber, layering, and advanced technique like in vitro culture. Reference [4] stated that $C$. vespertilionis can be progated using seed and stem cuttings. However, there is limited researcs.

\section{A. Germination test}

Seed was obtained from a local nursery at Kuala Terengganu, Terengganu Malaysia and cleaned from any dirt. There were four treatments tested: peat moss (control), wet paper towel, water soaking and immersion in hot water $\left(60^{\circ} \mathrm{C}\right)$ for 5 minutes. A total of ten seed per treatment and experiment were repeated twice. All samples were kept in the growth chamber at $28^{\circ} \mathrm{C}$ and the observation of the germinated seed were recorded after 24 hours. Germination rate was calculated based on [5].

\section{B. Cutting propagation}

Seedling and cutting were tested to compare their viability to growth. Cuttings were made from the mother plant. Two types of cutting were used which were softwood and semi- 
hardwood [6]. Softwood was defined as a stem with 4 nodes from the shoot tip and semi-hardwood was stem with the 4 nodes after the softwood. A fresh cut was dip into rooting promoting powder and inserted in hole of the growing medium. Cuttings and seedling (germinated seed) of $C$. vespertilionis were placed under the shade house for five weeks and general plant maintenance was applied such as watering and fertilization.

\section{In vitro propagation}

Nodal nodes of $C$. vespertilionis were collected from a healthy and disease-free mother plant. The explants were sterilized using liquid detergent, sterile distilled water, 0.1 $\%(\mathrm{w} / \mathrm{v})$ sodium hypochlorite, and $70 \%$ ethanol. Sterile explants were cultured into solidified Murashige and Skoog (MS) medium supplemented with different concentrations of shoot induction hormone 6-Benzyl amino purine (BAP) $(1.0,2.0,3.0 \mathrm{mg} / \mathrm{L})$, a cytokinin plant growth regulator. Shoot with two or three leaves were transferred into MS medium containing root induction hormone Indolebutyric acid (IBA) $(0.5,1.0,1.5 \mathrm{mg} / \mathrm{L})$. Each treatment was replicated five times and samples were arranged in a complete randomized design. Experiment were carried out for eight weeks in the culture room with 16 hours photoperiod light, temperature at $25-26{ }^{0} \mathrm{C}$ and $85 \%$ humidity.

\section{Statistical analysis}

Data analysis was perform using GenStat for Teaching and Learning (18th Edition), VSN International, United Kingdom. All data were subjected to one way ANOVA analysis and post hoc's test was further separated by Duncan Multivariate Range Test (MRT) for least significance at $\mathrm{p}<0.05$.

\section{RESULTS AND DISCUSSION}

Experiments in this study were conducted with the aim to evaluate the ability of sexual (seed) and vegetative (cuttings and in vitro) propagation techniques in producing sustainable planting materials of valuable medicinal plant C. vespertilionis. This information may be useful for farmers and conservation purposes.

\section{Seed germination test}

Based in Table 1, the significant germination rate $(\mathrm{p}<0.05)$ was found in the treatment of wet paper tissue compared to other treatments. The seed that was directly sowed in the peat moss and pre-treated with hot water $\left(60^{\circ} \mathrm{C}, 5 \mathrm{~min}\right)$ showed a moderate germination rate. Similarly, [7] found that pre-treatment used such as soaking in cool or hot water, had no significant effect on the germination seed of selected multipurpose woody species in Uganda. Most of the seed of $C$. vespertilionis that were pre-treated with water soaking for 24 hours failed to germinate. A possible explanation of this situation happens is due to the small size of the seed and thin seed coat which may lead to oxygen deficiency occurs [8].
Table 1. Percentage of seed germination rate of $C$. vespertilionis

\begin{tabular}{|l|l|c|}
\hline \multicolumn{2}{|l|}{ Treatment } & $\begin{array}{c}\text { \% Germination } \\
\text { rate }\end{array}$ \\
\hline T1 & Peat moss (control) & $19.17^{\mathrm{a}}$ \\
\hline T2 & Wet paper tissue & $57.50^{\mathrm{b}}$ \\
\hline T3 & Water soaking for 24 hours & $2.50^{\mathrm{a}}$ \\
\hline T4 & $\begin{array}{l}\text { Immersion in hot water } \\
60^{\circ} \mathrm{C} \text { for } 5 \text { min }\end{array}$ & $19.17^{\mathrm{a}}$ \\
\hline $\begin{array}{l}\text { Means followed by the same letter in the same column are not } \\
\text { significantly different at } p<0.05 \text { according to Duncan test. }\end{array}$
\end{tabular}

In order to evaluate plant growth performance, the seedlings from germination test were compared with different parts of cuttings. Based on Table 2, semihardwood cuttings showed significant performance compared to seedlings and softwood cuttings. Previously, [9] and [10] concluded that in the most ornamental plants, the success of woody stem cuttings depends on types of cutting, environmental conditions and species rooted. In this experiment, semi-woody cuttings produced the highest plant and vigorous branch and leaves. Reference [11] stated that semi-hardwood and hardwood gave the best rooting of Duranta repens.

Table 2. Growth response of different of types of cutting and seedlings of $C$. vespertilionis

\begin{tabular}{|c|l|l|l|l|}
\hline \multicolumn{2}{|c|}{ Treatment } & Height & $\begin{array}{l}\text { Number of } \\
\text { branch }\end{array}$ & $\begin{array}{l}\text { Number } \\
\text { of leaves }\end{array}$ \\
\hline T1 & Seedling & $5.47^{\mathrm{a}}$ & $7.50^{\mathrm{a}}$ & $7.17^{\mathrm{a}}$ \\
\hline T2 & $\begin{array}{l}\text { Softwood } \\
\text { cuttings }\end{array}$ & $19.17^{\mathrm{b}}$ & $9.50^{\mathrm{ab}}$ & $30.00^{\mathrm{b}}$ \\
\hline T3 & $\begin{array}{l}\text { Semi } \\
\text { hardwood } \\
\text { cuttings }\end{array}$ & $30.22^{\mathrm{c}}$ & $13.17^{\mathrm{b}}$ & $40.00^{\mathrm{b}}$ \\
\hline
\end{tabular}

The formation of in vitro shoots was observed within 4 weeks of culturing time. Treatment $2(2.0 \mathrm{mg} / \mathrm{L}$ BAP $)$ significantly $(\mathrm{p}<0.05)$ induced a higher number of shoots, length of shoot and fresh weight of plantlets compared to other treatments (Table 3). A similar finding was observed by [12] in vitro shoot formation of medicinal plant Ziziphora tenuior L. In this experiment, the used of single cytokinin plant growth regulator was able to induce multiple $C$. vespertilionis shoots (Figure 1). This finding in contrast with the studies carried out on Anisochilus carnosus (L) [13] and Lagenaria siceraria [14] where a combination of BAP and auxin were needed to produced multiple shoots. Explant in MS media supplemented with a high dose of cytokinin (BAP) showed poor induction of shoot and fresh weight which is in agreement with the findings of [15] and [16]. 
Table 3. Effect of different concentration of BAP plant growth regulator on shoot induction of $C$. vespertilionis.

\begin{tabular}{|l|l|c|c|c|}
\hline \multicolumn{2}{|c|}{ Treatment } & $\begin{array}{c}\text { Shoot } \\
\text { formation }\end{array}$ & $\begin{array}{c}\text { Length } \\
\text { of shoot }\end{array}$ & $\begin{array}{c}\text { Fresh } \\
\text { weight }\end{array}$ \\
\hline $\mathrm{T} 1$ & $1.0 \mathrm{mg} / \mathrm{L}$ & $1.40^{\mathrm{b}}$ & $0.46^{\mathrm{a}}$ & $56.80^{\mathrm{a}}$ \\
\hline $\mathrm{T} 2$ & $2.0 \mathrm{mg} / \mathrm{L}$ & $3.40^{\mathrm{c}}$ & $0.94^{\mathrm{b}}$ & $104.40^{\mathrm{b}}$ \\
\hline $\mathrm{T} 3$ & $3.0 \mathrm{mg} / \mathrm{L}$ & $2.20^{\mathrm{b}}$ & $0.42^{\mathrm{a}}$ & $68.80^{\mathrm{a}}$ \\
\hline $\mathrm{T} 4$ & $4.0 \mathrm{mg} / \mathrm{L}$ & $1.20^{\mathrm{a}}$ & $0.30^{\mathrm{a}}$ & $48.40^{\mathrm{a}}$ \\
\hline $\mathrm{T} 5$ & $5.0 \mathrm{mg} / \mathrm{L}$ & $1.40^{\mathrm{b}}$ & $0.34^{\mathrm{a}}$ & $58.20^{\mathrm{a}}$ \\
\hline \multicolumn{2}{|l|}{ Means followed by the same letter in the same column are not }
\end{tabular}

significantly different at $P<0.05$ according to Duncan test.
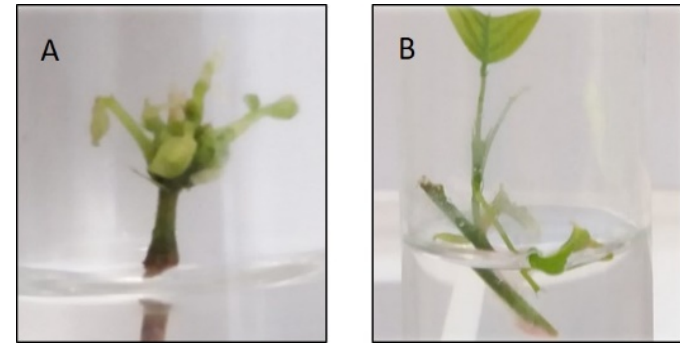

Figure 1. Example of in vitro shoot induction of $C$ vespertilionis (A: multiple shoot were induced using $\mathrm{BAP}$ $2.0 \mathrm{mg} / \mathrm{L}, \mathrm{B}$ : shoot elongation)

\section{CONCLUSION}

The result obtained from this study showed that the suitable germination method for $\mathrm{C}$. vespertilionis is a wet paper towel. Based on the propagation experiment, semi-woody cuttings develop a good propagated plant than soft woody and seedling. Meanwhile, from in vitro study, the optimum level of BAP to induced shoot for $C$. vespertilionis has been identified at $2.0 \mathrm{mg} / \mathrm{L}$. However, further investigation needs to be carried out to identify suitable rooting hormones for $C$. vespertilionis. These findings provide useful information for the sustainable reproduction of $C$. vespertilionis planting materials.

\section{ACKNOWLEDGMENT}

This study was funded by Universiti Malaysia Terengganu under Final Year Project Student Scheme. The authors would like to thank Mrs. Athirah Fatin Badrul Hisham for her help with the laboratory work of this study.

\section{REFERENCES}

[1] H. Bunawan, S. N. Bunawan, and S. N. Baharum. "The red butterfly wing (Christia vespertilionis): a promising cancer cure in Malaysia". International Journal of Pharmacy and Pharmaceutical Sciences, vol. 8 (8), 2015, p. 1, https://innovareacademics.in/journals/index.php/ ijpps /article/ view/6122.

[2] G. K. Dash, "An appraisal of Christia vespertilionis (L. F.) Bakh. F.: A promising medicinal plant" International Journal of Pharmacognosy and Phytochemical Research, vol. 8(6), 2016, pp. 1037-1039.

[3] D. Hofer, G. Schwach, N. Ghaffari Tabrizi-Wizsy, A. Sadjak, S. Sturm, H. Stuppner, and R. Pfragner, "Christia vespertilionis plant extracts as novel antiproliferative agent against human neuroendocrine tumor cells", Oncology Reports, vol. 29, 2013, pp. 2219-2226. https://doi.org/10.3892/or.2013.2367

[4] J. M. Barham, "Christia vespertilionis var. vespertilionis Leguminosae" Curtis's Bot. Mag., vol. 13, 1996, pp. 19-21.

[5] ISTA International rules for seed testing, "Seed science and Technology", 1999, pp. 21-288.

[6] L Schmidt, "Vegetative propagation. Guidelines on grafting, air-layering and cuttings", 1993, FAO, Rome (Italy).

[7] A. Nyamukuru, J. R. S. Tabuti, and P. R. Aduma, "Propagation and seedling establishment of selected multipurpose woody species of Uganda", International Journal of Biodiversity Science, Ecosystem Services \& Management, vol. 10(4), 2014, pp. 270-274. doi:10.1080/21513732.2014.953584

[8] B. I. Robertson and J. G. "Small, Germination of Jubaeopsis caffra seeds", Principles, vol. 21, 1977, pp. 114-122.

[9] J. M. Dole, and H. F. Wilkins, Floriculture: Principles and Species., Prentice Hall, Upper Saddle River, N.J. 2nd ed. 2005, 558 pp.

[10] J. S. Day, and B. R. Loveys, "Propagation from cuttings of two woody ornamental Australian shrubs Boronia megastigma and Hypocalymna angustifolium Endl. (white myrtle)", Australian Journal of Experimental Agriculture, vol. 38, 1998, pp. 201-206.

[11] O. A. Ibironke, "The Effects of Cutting Types and Length on Rooting of Duranta repens in the Nursery", Global Journal of Human-Social Science Research, vol. 13, 2013, No 3-B, Retrieved from https://socialscienceresearch.org/index.php/GJHSS/ article/view/774.

[12] A. Dakah, S. Zaid, M. Suleiman, S. Abbas, and M. Wink, "In vitro propagation of the medicinal plant Ziziphora tenuior L. and evaluation of its antioxidant activity", Saudi Journal of Biological Sciences, vol. 21(4), 2014, pp. 317-323. doi:10.1016/j.sjbs.2013.12. 002 .

[13] N. A. Reshi, M. S. Sudarshana and H. V. Girish, "In Vitro Micropropagation of Anisochilus carnosus (L) Wall", Journal of Applied Pharmaceutical Science, vol. 7 (07), 2017; pp.098102.

[14] S. Saha, H. Mori, and K. Hattori, "Synergistic Effect of Kinetin and Benzyl Adenine Plays a Vital Role in High Frequency Regeneration from Cotyledon Explants of Bottle Gourd (Lagenaria siceraria) in Relation to Ethylene Production", Breeding Science, 2007, vol. 15(7), pp.197-202.

[15] V. N. Nathar, and G. M. Yatoo, "Micropropagation of an Antidiabetic Medicinal Plant, Artemisia pallens", Turkish Journal of Botany, vol. 38, 2014, pp. 491-498.

[16] D. B. Indhra, and U. Dhar, "Micropropagation of Indian Wild Strawberry", Plant Cell Tiss Organ Culture, vol. 60, 2000, pp. 83-88. 